setting up inquiries into topics such as the relations between research councils and universities is one sign that the board has woken up. Another is an important discussion, now published, of the demographic problems presented by the maldistribution of university teachers in most disciplines, a consequence of the rapid expansion of the 1960s. As elsewhere, there are too few young people and too many who are middle-aged (see chart, p.8). Much of the redirections of science spending planned for the next few years is intended to redress this balance, and not before time. The obvious danger is that by using money intended for research to improve the condition of British universities, the research councils may be helping to break the board's rule that they should not attempt to make good the deficiencies of the dual-support system. The snag is that self-restraint in that regard requires not merely that the councils should back good people, but that they should do so only if those people are well placed to carry out research effectively. So why should not the board spell out the criteria it expects that its dependants will follow?

A more awkward question needs to be taken up (in next year's review?): are the board's dependants as efficient as they should be? In the past few years, the peer-review systems operated by most of the research councils have won widespread respect, but many of their own research establishments fall far short of what they might be. Perhaps the most conspicuous example is the Medical Research Council's National Institute for Medical Research, which has long been balkanized into "divisions" that hardly ever speak to each other and where even minor items of expenditure must be met by cheques paid from headquarters. The board now repeats the research council's promise that its institute will be "restructured", and has appointed Dr D. A. Rees to that unenviable task. But who is to say that this one institute is not just the visible tip of a much larger problem?

Old-fashioned ways of delegating financial responsibility are certainly not confined to one institute or even to one research council. And all those that depend to some extent on contracts with government departments for the conduct of applied research are necessarily caught up in a complicated set of negotiations that only occasionally leads to a change in the pattern of expenditure. Similarly, the recruitment of extra staff within the research council system is hampered by rules dictated from on high which are designed to limit the total strength of the public service, but which prevent research council establishments from earning honest money when they can. The British Prime Minister's favourite cost-cutter, Sir Derek Rayner, is thought recently to have turned his attention to the research councils. It will be best for everybody if he discovers that the present system is too much hamstrung from outside.

The most serious defect in the working of the advisory board, now revealed, is however the incompleteness of such authority as it enjoys even in the field with which it is concerned. (The case that there should be some mechanism for overseeing the whole of publicly-supported research, defence research included, is irresistible but nevertheless repeatedly denied.) The board's membership includes most of the chief scientists of government departments which are in their own right substantial sponsors of research, much of it in universities, little of it different in kind from work sponsored by the research councils. The British government has firmly rejected the argument of the House of Lords Select Committee that there should be some device for overseeing the whole of public sponsorship of research and development, partly on the grounds that the present prime minister has a personal interest in the subject. But can it make sense that government departments, from health to industry, should be caught up in a semi-judicial (but over-casual) assessment of what the research councils should be allowed to do when their own spending in similar fields is innocent of outside inquiry? The simple answer, which all bureaucrats will echo, is that what the advisory board calls the science budget is a charge on the Department of Education and Science, and that there would be departmental barriers to a more wide-ranging inquiry. But it makes no sense that such procedural matters should inhibit what good sense requires.

\section{Vatican and the bomb}

\section{A group of scientists has given the Pope a tactless declaration on nuclear warfare.}

The Pontifical Academy of Sciences is not an academy in the strict sense (its members are invited by the Vatican) but it seems well on the way to being pontifical. The statement put out at the end of September is thus a sombre warning of the dangers of nuclear war from which few will dissent, a stern proscription of steps that might trigger off such a war and an appeal to those concerned - politicians, scientists, religious leaders "and other custodians of moral principles" - to use their best influence for the avoidance of nuclear war. The statement is a remarkable document if only because of the distinction of those who have signed it - the list includes, for example, the presidents of the National Academy of Sciences of the United States (Dr Frank Press) and of the Royal Society (Sir Andrew Huxley), acting in their personal capacities. Its weakness is that the pursuit of agreement on a set of statements about nuclear war with which nobody can quarrel seems to have obscured the more immediate issues that must be dealt with.

Even the analysis of the problem of nuclear warfare in the published statement falls short in clarity of what the members of the group individually would suggest. Thus the statement says that "there appears to be a growing fatalistic acceptance that war is inevitable and that wars will be fought with nuclear weapons". Can that be so? At a time when there are more (and more hopeful) negotiations on the limitation of nuclear weapons under way than in the past three decades? Or when military authorities are seriously considering the possibility of defending Western Europe with conventional rather than nuclear weapons? It is true, of course, that political relations between East and West in Europe have deteriorated in the past year, for which reason it is all the more remarkable that the arms negotiators in Geneva are still talking to each other, however desultorily. Similarly, it does not follow, as the Pontifical Academy of Sciences suggests, that "proliferation of nuclear weapons to additional countries seriously increases the risk of nuclear war and could lead to nuclear terrorism'". If anything, the argument should be turned around: as deep and apparently irreconcilable conflicts between sovereign powers become embittered (the Middle East?), the danger that one or other party will seek nuclear weapons increases. Proliferation (of which there has been mercifully little so far) is more likely to be a symptom than a cause.

The academy's recipe for action is similarly clouded. September's statement sanely asks that nations should renew their efforts to negotiate effective arms control agreements. The distinction of the participants should carry some weight, both in Geneva and in the continuing anxiety about the design of more effective measures for safeguarding the civil trade in nuclear power. But national governments are also asked "never to be the first to use nuclear weapons"'. Can that be seriously intended? For most of the signatories of the document must be fully aware that this is an extremely contentious issue. In Europe, the Soviet Union has repeatedly offered a "declaration of no first use", and its Western opponents have as steadfastly refused a deal. The reasons, moreover, are well understood. Either such a declaration means nothing, or it will favour that adversary in some future conflict which is weaker in conventional forces. To couple an appeal for more serious negotiations on arms control with a declaration calculated to lose the sympathy of many of those who will read the statement is tactless, to say the least.

What can be accomplished by such manifestos? There are two choices. Either a statement on some public issue can be so penetrating and original in its analysis of a problem, or so arresting in its description of it, that ordinary people will stop and think. Or it may so powerfully suggest new things to do that statesmen will be compelled by sheer logic to follow the course prescribed. This statement on nuclear warfare is, unhappily, neither one thing nor the other. 